Thermal Management of Electronic Systems 


\section{Thermal Management of Electronic Systems}

Proceedings of EUROTHERM Seminar 29, 14-16 June 1993, Delft, The Netherlands

Edited by

C. J. HOOGENDOORN,

R. A. W. M. HENKES

J. M. Burgers Centre for Fluid Mechanics,

Delft University of Technology,

Delft, The Netherlands

and

C. J. M. LASANCE

Philips B.V.

Eindhoven, The Netherlands

SPRINGER-SCIENCE+BUSINESS MEDIA, B.V. 
A C.I.P. Catalogue record for this book is available from the Library of Congress.

ISBN 978-94-010-4472-1 ISBN 978-94-011-1082-2 (eBook)

DOI 10.1007/978-94-011-1082-2

Printed on acid-free paper

All Rights Reserved

(C) 1994 Springer Science+Business Media Dordrecht

Originally published by Kluwer Academic Publishers in 1994

Softcover reprint of the hardcover 1st edition 1994

No part of the material protected by this copyright notice may be reproduced or utilized in any form or by any means, electronic or mechanical, including photocopying, recording or by any information storage and retrieval system, without written permission from the copyright owner. 


\section{CONTENTS}

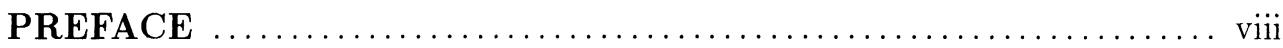

ACKNOWLEDGEMENTS $\ldots \ldots \ldots \ldots \ldots \ldots \ldots \ldots \ldots \ldots \ldots \ldots \ldots \ldots \ldots \ldots \ldots$

1. INVITED LECTURES $\ldots \ldots \ldots \ldots \ldots \ldots \ldots \ldots \ldots \ldots \ldots \ldots \ldots \ldots \ldots$

Thermal management of air-cooled electronic systems:

New challenges for research.

C.J.M. Lasance ................................................... 3

Analysis and prevention of thermally induced failures in electronic equipment.

A. Bar-Cohen and S. Witzman ................................ 25

\section{NUMERICAL AND EXPERIMENTAL ANALYSIS}

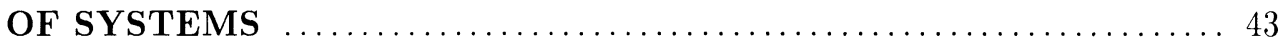

Computational analysis of air and heat flow in electronic systems.

S. Drake, M. White, A. Felthouse, C. Ganderton and S. Glanfield ........... 45

Thermal analysis of a telecommunications rack system.

J.D. Parry and D.G. Tatchell ................................ 55

Supporting experiments for CFD based thermal design of telecommunication equipment.

H. Bruneel, B. Beernaert, G. Mortier, J. Declercq,

B. Boesmans, W. Temmerman, W. Nelemans and E. Lauwers .............. 65

Two complementary approaches for the thermal simulation of electronic equipment.

J.L. Blanchard and J.M. Morelle ................................. 75

Some considerations on practical formulas used for thermal design of natural ventilated enclosures.

M. Misale 


\section{NUMERICAL AND EXPERIMENTAL ANALYSIS}

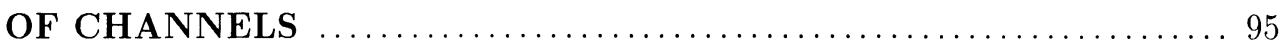

Natural convection in a rectangular enclosure with an array of chips mounted on a vertical wall.

C. Di Perna, A. Evangelisti, M. Paroncini and R. Ricci ................ 97

Differences between 2D and 3D models predictions in a channel with a dissipating obstacle.

J.B. Saulnier, H.Y. Wang and B. Fourka .......................... 107

Effect of radiation on natural convection in tilted channels.

O. Manca, S. Nardini and V. Naso ............................... 117

\section{NUMERICAL AND EXPERIMENTAL ANALYSIS} OF ELECTRONIC PARTS

Thermal study of a laser diode using a finite element method associated with a meshing superimposition method.

N. Ottavy, M. Bourhrara, J.-P. Le Jannou and P. Paris

Computer-aided optimization of electrothermal

CMOS-compatible infrared sensors.

G. Wachutka, J. Funk and H. Baltes

Mixed convection and heat transfer on vertical parallel printed circuit boards.

S. Mergui and F. Penot ......................................... 149

A parametric study of heat spreading through multiple layer substrates.

J. Punch and M. Davies

Thermal drift effects in power microwave hybrid circuits.

J. Alkhoja, D. Rauly and F. Grandjean

Computational modelling of wafer cooldown in a staging module.

K. Nederveen

\section{MEASUREMENT TECHNIQUES}

Recent innovations in thermal technology instrumentation applied to materials used in electronic applications.

R.P. Tye and R.L. Gardner ................................... 191

An experimental method to determine the effective thermal conductivity of printed circuit boards.

H.J.L. Vanlaer and C.J.M. Lasance.

Air velocity and temperature measurements around a naturally convecting rectangular fin array.

P. Rodgers and M. Davies 


\section{LIQUID COOLING OF ELECTRONIC DEVICES}

Application and performance of Si-microcooling systems for electronic devices.

B. Gromoll

Temperature controlled measurements of the critical heat flux on microelectronic heat sources in natural convection and jet impingement cooling. K. Köberle and H. Auracher .................................. 233

Pool boiling heat transfer of dielectric fluids for immersion electronic cooling: effects of pressure.

G. Guglielmini, M. Misale and C. Schenone .......................... 243

7. THERMAL CHARACTERIZATION OF ELECTRONIC PARTS

Thermal design of a 419 pins ceramic Pin Grid Array package.

T. Fromont .................................................. 257

Design of an optimal heat-sink geometry for forced convection air cooling of multi-chip modules.

B. Boesmans, F. Christiaens, J. Berghmans and E. Beyne

Thermal characterization and design for high performance multichip module type laminate.

E. Lauwers, A. Ackaert, K. Allaert, W. Temmerman,

W. Nelemans and T. Goossens ................................... 277

The thermal characteristics of a board-mounted 160 lead plastic quad flat pack.

M. Davies, J. Lohan, J. Punch and T. Moore ........................ 287

Investigation of die attach integrity using transient thermal analysis techniques.

D. Liu, J. Barrett and S.C. Ó Mathúna

8. THERMAL STRESS AND DIE ATTACH DEFECTS

Thermal stress in convectively-cooled plastic-encapsulated chip packages.

S. Witzman, D.E. Mix and A. Bar-Cohen ........................... 309

Impact of die attach defects on internal temperature of power hybrids.

F. Michard, J.M. Dupont, H. Ribot and M. Salagoity

Author Index 


\section{PREFACE}

The Eurotherm Committee has chosen Thermal Management of Electronic Systems as the subject of its 29th Seminar, at Delft University of Technology, the Netherlands, 14-16 June 1993. This volume constitutes the proceedings of the Seminar.

Thermal Management is but one of the several critical topics in the design of electronic systems. However, as a result of the combined effects of increasing heat fluxes, miniaturisation and the striving for zero defects, preferably in less time and at a lower cost than before, thermal management has become an increasingly tough challenge. Therefore, it is being increasingly recognised that cooling requirements could eventually hamper the technical progress in miniaturisation.

It might be argued that we are on the verge of a revolution in thermal management techniques. Previously, a packaging engineer had no way of predicting the temperatures of critical electronic parts with the required accuracy. He or she had to rely on full-scale experiments, doubtful design rules, or worst-case estimates. This situation is going to be changed in the foreseeable future. User-friendly software tools, the acquisition and integrity of input and output data, the badly needed training measures, the introduction into a concurrent engineering environment: all these items will exert a heavy toll on the flexibility of the electronics industries. Fortunately, this situation is being realised at the appropriate management levels, and the interest in this seminar and the pre-conference tutorials testifies to this assertion.

The Organising Committee succeeded in assembling an interesting programme embracing over 35 oral and poster presentations, four invited lectures, two pre- conference tutorials, a special session on European co-operation, and exhibits. It is a pleasure to look back and conclude that the seminar was a great success. About 100 people from 12 different countries attended the seminar, which was well above expectations. The same holds for the two tutorials, about 25 persons each participated. The subjects of the papers are equally divided between numerical and experimental analysis, which clearly shows that experimental work is by no means a dead end. The exhibition provided the opportunity to have a look at the newest versions of today's thermal analysis software and some very interesting products as well. A survey of the exhibitioners can be found under the Acknowledgements, where we take the opportunity to thank them for their financial support.

However, despite its success, other initiatives are needed as well. It is the objective of the Eurotherm Seminars to be a popular forum for high-level scientific and technical interchange of ideas on a wide range of special topics, while the primary aim is to stimulate discussion and liaison between specialists groups. Dr. Kaveh Azar, chairman of the 8th SEMI-THERM conference, Austin, 1992, said in his preface: "SEMI-THERM is perhaps the only conference that provides a medium to present current and near future development work. It also attempts to merge contributions from the universities and industrial communities." 
We would be happy if the 'thermal management' community in Europe could establish the same tradition in communication as our colleagues in the USA, and one of the most appropriate ways is to organise an Eurotherm seminar like this on a regular basis. After the lively session on European coordination, it was decided to organise a Thermal Management seminar every two years. IMEC in Leuven, Belgium, volunteered to take the initiative for 1995.

We would like to acknowledge the contribution of the Scientific Committee for helping us to ensure the quality of the proceedings, and we would also like to thank the authors, invited speakers and tutorial lecturers for their valuable contributions to the success of this seminar. We owe many thanks to Mrs Sharmila Sewmar, who managed to stay in control of the many things that had to be done, and still remain smiling, besides her normal job as secretary to professor Hoogendoorn.

We are very grateful to the J.M. Burgers Centre for Fluid Mechanics, the host of the seminar, which got many compliments on the perfect organisation, the very nice facilities and the general ambiance of the old city of Delft.

\section{C.J. Hoogendoorn, R.A.W.M. Henkes and C.J.M. Lasance, editors}




\section{ACKNOWLEDGEMENTS}

\section{exhibition participants}

Cadence Design Systems BV

Bruistensingel 380

5232 AE Den Bosch

The Netherlands

Tel.: 3173429500

Fax: 3173429679

CHAM

Bakery House

40 High Street, Wimbledon Village

London SW19 5AU

ENGLAND

Tel.: 44819477651

Fax: 44818793497

FLOMERICS Ltd

Kingsgate Business Centre, 12-50

Kingsgate Road,

Kingston upon Thames

Surrey KT2 5AA

England

Tel.: 44815473373

Fax: 44815472682

Mentor Graphics

Benelux Regional Office

Haarlemmerstraatweg 133-137

1165 MK Halfweg

The Netherlands

Tel.: 3129077115

Fax: 3129076532
Powercool Europe BV

Echtenseweg 10

7963 PC Ruinen

The Netherlands

Tel.: 3152212497

Fax: 3152212675

Power Electronics Ireland

EOLAS

Glasnevin

Dublin 9

Ireland

Tel.: 35361333644

Fax: 35361330316

Sensor Partners

P.O. Box 270

5150 AG Drunen

The Netherlands

Tel.: 31416378329

Fax: 31416377439

THERMACORE Inc.

780 Eden Road

Lancaster, PA 17601

USA

Tel.: 17175696551

Fax: 17175694797 